Conference Paper

\title{
The Effects of Organizational Design on Hospital Nurse Burnout and Performance
}

\author{
Friska Sipayung*, Liasta Ginting, Magdalena L. L. Sibarani \\ University of Sumatera Utara, Medan, Indonesia
}

*Corresponding author:

E-mail: riska@usu.ac.id

\begin{abstract}
Every company needs an understanding of organizational design to achieve a sustainable competitive advantage. Thus, researching organizational architecture, burnout, and efficiency is important to increase organizational performance, design organizational structures, and maintain a low level of burnout. The findings indicated that respondents had a mostly favorable opinion of organizational architecture, while nurses registered low levels of burnout and high levels of efficiency social assistance questionnaire. and a documentation analysis was used to gather evidence. Study of paths using the Partial Least Squares algorithm The smart PLS method was used to analyze the data in this thesis. (PLS). The findings indicated that respondents had a mostly favorable opinion of organizational architecture, while nurses registered low levels of burnout and high levels of efficiency. In this analysis, the organizational architecture of health care organizations is mechanistic. This is described as a high level of formalization and centralization, and a lack of planning or work experience, among other characteristics. The results showed that organizational design affected burnout. Organizational design affects performance. Organizational design and burnout affect performance.
\end{abstract}

Keywords: Organizational design, burnout, and performance

\section{Introduction}

The effectiveness of individuals, groups, and organizations, apart from being influenced by organizational behavior and processes, is also influenced by organizational structure (Robbins, \& Judge, 2009) For an organization, the most important thing for an organization to achieve its goals is that the organization must have an organizational design or structure that supports strategic planning. The method of choosing and enforcing the ideal framework for handling capital to accomplish objectives is called organizational design. The goal of organizational design is to use a structure that facilitates the implementation of the strategy. Organizational design can also be expressed as a decision-making process carried out by managers to choose an organizational structure that fits the strategy for the organization and the environment in which organizational members carry out these strategies. However, many organizations are less able to design structures according to the objectives of the organization's strategic planning. This situation causes the organization to fall short of achieving its goal and mission. One of an executive's or manager's primary responsibilities is to plan and execute corporate policy, which includes compiling organizational architecture. It is crucial that strategic planning and organizational architecture operate in parallel. The vulnerability that has been found so far is executives' and managers' failure to consider this. As a result, it is critical to have a more nuanced view of how to design an enterprise in a manner that is compatible with the organization's overall strategic planning.

The way management designs the organization must keep in mind this dimension of the organizational structure. How they are combined has a profound influence on their success. Individuals, groups, and associations are all distinct organizations. When managers build an organization, they must take a variety of considerations into account. There are two approaches to organizational design: mechanistic and ecological. The mechanistic model is an organizational structure that places a premium on high and

\section{How to cite:}

Sipayung, F., Ginting, L., \& Sibarani, M. L. L. (2021). The effects of organizational design on hospital nurse burnout and performance. $1^{\text {st }}$ ICEMAC 2020: International Conference on Economics, Management, and Accounting. NST Proceedings. pages 267-279. doi: 10.11594/ nstp.2021.1032 
productive performance through the intensive use of rules and procedures. Centralization of power and elevated levels of labor specialization. In terms of operational features and procedures, the organic model is in a position distinct from the mechanistic model. The true distinction between the two models is a result of the two models' differing efficacy requirements, both of which aim to maximize. While the mechanistic model maximizes efficiency and the production of the organic model maximizes satisfaction, flexibility, and development (Gibson, et al., 2008)

At work, the design organization has a direct effect on work attitudes and determines employee performance. A good design organization makes employees' attitudes positive and encourages them to work harder and better. On the contrary, they tend to Leave the environment will result in burnout.

Although the word "burnout" is difficult to describe, it is easier to understand the symptoms, which include reduced morale, high absenteeism, and psychological distress among workers (Dessler, 2015) A well-designed organization can eliminate the pressures that contribute to fatigue. According to Robbin and Judge (2009), organizational design may also lead to burnout, especially the degree of distinction within the organization and the degree of centralization, which prevents workers the ability to engage in decision-making. Numerous studies have established a connection between organizational design and burnout and its effect on success. A well-designed organization may have a beneficial impact on employee satisfaction and individual efficiency (Utami, 2005). According to research conducted by Kurniawati and Solikhah (2012), burnout has a major impact on job satisfaction and success. According to Robbin and Judge (2009), organizational design may also contribute to burnout, especially the degree of distinction within the group and the degree of centralization, which denies workers the ability to engage in decision-making. Job burnout becomes a challenge for companies because it results in reduced efficiency, as well as decreased productivity (Dale, 2011). Hakim and Windijarto (2016) concluded that self-efficacy and burnout affected results. Simultaneously or partly, self-efficacy and burnout have a significant correlation, with the higher an employee's self-efficacy, the greater his faith in his abilities to perform productively. Burnout has a detrimental impact on job satisfaction, which suggests that the more burned out an employee is, the poorer their efficiency. Additionally, the combination of self-efficacy and burnout has a major impact on the success of PT Semen Indonesia workers.

Realizing how organizational design has a significant contribution to each individual in the organization and even causes burnout, which in turn will also affect performance. The researcher feels that a good understanding of organizational design and there is a requirement for burnout. The following is the formulation of the study problem:

1. What is the hospital organization design, does the model tend to be mechanistic or organic?

2. Do organizational design affect burnout?

3. Do organizational design affect performance?

4. Do organizational design and burnout affect performance?

\section{Literature Review}

\section{Organization design}

Mechanical and organic models

The importance of design decisions after stimulating a great deal of interest in the subject matter. Managers who face the need to design organizational structures are in a position not to lose out on ideas. There are two general organizational design models, namely mechanistic and organic models (Gibson et al., 2008).

The mechanistic model is an organizational design that emphasizes the importance of achieving high and efficient production through extensive use of rules and procedures, centralization of authority, and high workforce specialization. The Organic Model of organizational design is in a position as opposed to the mechanistic model about differences in organizational features and procedures. The very real distinction between the two models is a result of the two models' disparate efficacy requirements, both of which seek to maximize. While the mechanistic model maximizes efficiency and the production of 
the organic model maximizes satisfaction, flexibility, and development. Organic organizations are flexible to changing environmental demands because organic organizational designs encourage greater utilization of human potential. Communication flows throughout the organization, not just down the line of command. Table 1 shows some of the differences between the mechanistic organizational model and the organic model of organization.

Table 1. Models of mechanical and organic structure

\begin{tabular}{|c|c|}
\hline Process & Mechanistic Model Structure \\
\hline Leadership & $\begin{array}{l}\text { Subordinates feel free to discuss problemsSubordinates feel free to discuss problems } \\
\text { with superiors } \\
\text { with superiors. }\end{array}$ \\
\hline Motivation & $\begin{array}{l}\text { The process of motivation only taps intoThe motivation process tries to generate } \\
\text { physical, security, and economic motivesmotivation through the participatory } \\
\text { through feelings of fear and sanctions. method. }\end{array}$ \\
\hline $\begin{array}{l}\text { Communica- } \\
\text { tion }\end{array}$ & $\begin{array}{l}\text { The communication process takes place inThe communication process takes place in } \\
\text { such a way that the downward flow of infor-such a way that information flows freely } \\
\text { mation tends to be distracted, inaccurate,throughout the organization, namely up, } \\
\text { and viewed with suspicion. } \\
\text { down, and sideways. }\end{array}$ \\
\hline Interaction & $\begin{array}{l}\text { The interaction process is closed and limited The interaction process is open and exten- } \\
\text { sive. }\end{array}$ \\
\hline Decision & $\begin{array}{l}\text { The Decision-making process takes placeThe decision-making process is carried out } \\
\text { only at the top level } \\
\text { at all levels through a group process. }\end{array}$ \\
\hline Goal Setting & $\begin{array}{l}\text { The process of setting goals is carried out at The process of setting goals encourages } \\
\text { the top level of the organization without en-group participation to set high goals } \\
\text { couraging participation. }\end{array}$ \\
\hline Control & $\begin{array}{l}\text { The control process is center and empha-Process control spreads throughout the or- } \\
\text { sizes the effort to smooth over the mistakesganization and emphasizes problem solv- } \\
\text { that occur. } \\
\text { ing and self-control. }\end{array}$ \\
\hline
\end{tabular}

Source: Daft, 2016

The mechanistic organizational model is a model that emphasizes the importance of achieving high levels of production and efficiency. Fayol in (Daft, 2016) mentions some principles related to the function of leadership to organize and some of them are related to understanding the mechanistic model, namely:

1. The Principle of Specialization. The best means of empowering individuals and groups.

2. The Principle of Unity of direction. All jobs must be grouped by expertise.

3. Principle of Authority and Responsibility. Managers must be delegated sufficient authority to carry out the responsibilities assigned to them.

4. Principle of Scalar Chains. The natural result of implementing the three preceding principles is a chain of managerial levels from the highest rank to the lowest rank. Scalar chains are the overall vertical lines of communication in an organization.

The organic model of organization emphasizes the importance of achieving high levels of adaptation and development. This organizational design relies less on rules and procedures, centralized authority, or high specialization (Gibson et al., 2008). The organic model of organization is in contrast to the mechanistic model. The organizational characteristics and practices underlying the organic model are completely different from the characteristics and practices underlying the mechanistic model. The most striking distinction between the two models comes from the disparate effectiveness parameters that each model strives to meet. Whereas the mechanistic model aims for maximum productivity and development, the organic model aims for maximum adaptability and flexibility. Organic organizations are adaptable and resilient in response to external changes, as their corporate systems allow them to optimize 
human potential. Organization-al designs that evoke a sense of worth and motivation and facilitate flexibility and adaptability usually have the following characteristics:(Daft. 2016).

1. Relatively simple because it does not require specialization, but emphasizes increasing the scope of work.

2. Relatively decentralized because it emphasizes delegation of authority and increasing work depth.

3. Relatively formal because it emphasizes the product and customer as the basis of departmentalization

\section{Organizational design dimensions}

According to Daft (2016), the organizational design dimension consists of two types, namely the Structural Dimensions and Contextual Dimensions.

1. Structural Dimensions, namely dimensions that describe the internal characteristics of the organization and create a basis for measuring and comparing organizations. The structural dimensions consist of:
a. Formalization
b. Specialties
c. Standardization
d. Hierarchy of Authority
e. Complexity
f. Centralization
g. Professionalism
h. Personnel ratio

2. Contextual Dimensions, namely dimensions that describe the entirety of an organization. This dimension shows the organizational structure that affects and forms an organizational structural dimension, which consists of:
a. Size
b. Organizational Technology
c. Environment

\section{Burnout}

\section{Burnout dimensions}

Burnout is a complex phenomenon. Burnout is increasingly being recognized as a serious problem affecting many people, especially in services companies. Job burnout is a chronic emotional and interpersonal stress response to prolonged work (Maslach et al., 2001). More specifically, it involves the chronic tension that results from a mismatch, or mismatch, between workers and jobs. In the multidimensional model of the burnout phenomenon, there are three key dimensions, including fatigue, feelings of cynicism and type of work, and feelings of ineffectiveness and lack of achievement. According to Maslach et al. (2001), burnout is different from job stress. Burnout is a physical state, emotional exhaustion, and it is caused by a long-term commitment to demanding situations. It has been described as a feeling of helplessness and hopelessness, low energy levels, chronic fatigue, fatigue, and a feeling of being trapped. There are also negative feelings for yourself, work, and life. Burnout is a condition in which individuals experience a condition of emotional exhaustion that occurs for a long time and cause changes in negative attitudes and behaviors. According to Maslach (2001) states that burnout has three dimensions which include emotional exhaustion, depersonalization, and perceived inadequacy of professional accomplishment.
a. Emotional Exhaustion
b. Depersonalization
c. Personal Accomplishment 
Meanwhile, Baron and Greenberg (1997), also suggest four aspects of burnout, namely: 1. Physical fatigue 2. Fatigue 3. Mental fatigue is characterized 4. Low self-respect

\section{Factors that can cause burnout syndrome}

1. External factors. The factors that affect burnout are broadly divided into two, namely, external factors and internal factors. The several external factors affect burnout syn-drome, namely:

a. Role ambiguity.

b. Role conflict.

c. Workload

d. Support from superiors.

e. Support from family.

f. Organizational climate

g. Organizational culture.

h. Satisfaction with compensation.

i. Work performance.

j. Organizational Commitment.

k. Work motivation. Internal Factors

2. Internal factors that can affect burnout syndrome are:

a. Demographic factors include gender, age, education level, marital status, and years of service.

b. Personality factors consisting of personality type, self-esteem, and locus of control.

In this study, researchers used the Leatz \& Stolar burnout dimensions namely (a) physical exhaustion (b) emotional fatigue (c) mental fatigue (d) low self-esteem, self-esteem, (e) personalized. This study also uses two factors that influence burnout, namely external factors, and internal factors. External factors consist of:
a. Role ambiguity
b. A role conflict is a conflict that occurs because a person has more than one conflicting role.
c. Workload
d. Support from superiors.
e. Support from family
f. Organizational climate
g. Demographics
h. Self-esteem
i. Locus of control
j. Organizational culture
k. Satisfaction with compensation
1. Job performance
m. Organizational commitment
n. Work motivation

The Maslach Burnout Inventory (MBI) is the most commonly used instrument for assessing burnout (Maslach et al., 2001). It is intended to evaluate three dimensions of burnout syndrome. Burnout is expressed by using a measuring instrument in the form of a scale adapted from the Maslach Burnout Inventory scale. It is arranged based on three dimensions including Emotional Exhaustion (emotional saturation), Depersonalizing, and Personal Accomplishment (personal achievement). The scale is a rating scale with a scale range of $0-10$. The higher the burnout score, the higher the employee's tendency to experience burnout. Conversely, the lower the burnout score, the lower the burnout tendency of the employees. This tool has been proven reliable, valid, and easy to run. This measuring instrument has a total of 22 items. The Maslach Burnout Inventory Scale (MBI) is as shown in the following table. 
Table 2. Measurement of burnout rate based on the Maslach Burnout Inventory (MBI) scale

\begin{tabular}{llll}
\hline \multirow{2}{*}{ MBI Subs-cale } & \multicolumn{3}{l}{ Experience Burnout Rate } \\
\cline { 2 - 4 } & Low & Moderate & High \\
\hline$\square$ Emosional Exaustion & $<15$ & $15-23$ & $>23$ \\
$\square$ Depersonalization & $<0$ & $4-8$ & $>8$ \\
$\square$ Personal Achievement & $>36$ & $30-36$ & $<30$ \\
\hline
\end{tabular}

Source: Maslach (2001)

\section{Performance}

\section{Dimensions and performance indicators}

Performance is the result or output of a process. According to the behavioral approach in management, performance is the quantity or quality of something produced or services provided by someone who does the job (Luthans, 2011). Performance is work performance, namely the comparison between work results and the standards set (Mondy \& Mondy, 2008). Performance is an important factor that contributes to improving results, enhancing positive behavior and employee characteristics, and help to increase organizational productivity. Employee performance is the result of the standard and quantity of work accomplished by an individual in carrying out his or her duties promptly with the positions assigned to him or her (Mangkunegara, 2015). Person success is usually defined by three variables, according to Deslerr (2015) abilities to perform work; the working environment, which involves the equipment, resources, and knowledge required to perform the job; and inspiration for the desire to perform work.

The end objective of any effort made personally, in groups, or organizations is performance (Suandi et al., 2014). Employee efficiency is inextricably linked to the company's competitiveness and progress in meeting its objectives (Fitriastuti, 2013). Managing job performance is critical to achieving the organization's objectives. To control employee performance efficiently, organization management must be aware of and consider the factors that impact employee performance. Since managers can quickly identify options and make appropriate choices about employee results as they understand this (Fitriastuti, 2013).

According to Robbins and Judge (2009), the dimensions and performance indicators are as follows:

1) Quality.

2) Quantity.

3) On-time.

4) Effectiveness.

5) Independence.

The states that there are seven performances indicators, namely:

1) Purpose

2) Standard

3) Feedback

4) Tools and Facilities

5) Competence

6) Motive

7) Opportunities

The suggests performance indicators in terms of performance aspects, there are eleven aspects of performance, namely:
1) Loyalty
2) Job performance
3) Honesty
4) Discipline
5) Creativity 

6) Cooperation
7) Leadership
8) Personality
9) Initiative
10)Proficiency
11)Responsibility

\section{Factors affecting performance}

According to Keith Davis in Mangkunegara (2015), the factors that influence performance include:

a) Ability

b) Motivation

Gibson et al. (2008) states, there are 3 (three) factors that affect performance:

a) Individual Factors

Ability, skills, family background, work experience, social level, and demographics of a person.

b) Psychological Factor

Perceptions, roles, attitudes, personality, motivation, and job satisfaction

c) Organizational Factors

Motivation, job design, leadership, reward system.

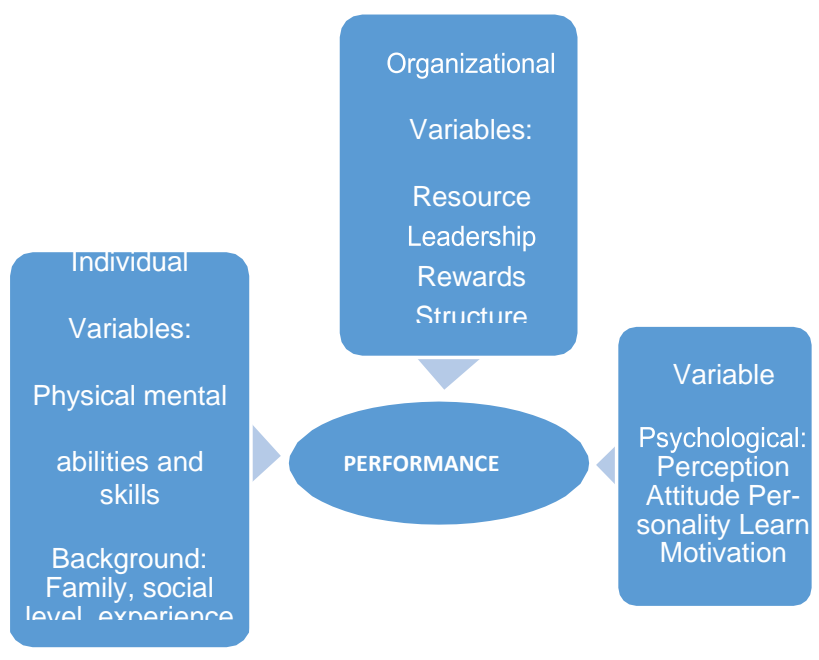

Figure 1. The three factors that influence performance (Source: Gibson, 2008)

There are three factors in an organization that can be a source of burnout, namely: 1. Organizational Design. 2. Leadership 3. Social interaction and support from colleagues. Organizational design has four important components that can cause burnout, namely: a) The structure of roles, in this condition can cause burnout through role conflicts and role ambiguity b) Role conflict and role ambiguity, which states that individuals experience difficulty in carrying out job demands which can cause individuals to feel that individual success in work is impossible. Individuals feel unable to change work situations and minimize role conflict and role ambiguity so that individual feelings of helplessness will lead to emotional withdrawal behavior; c) The power structure in the human service program. Several tasks must be carried out by the individual so there will be several decisions to be made. Some decisions that affect individual performance are made by the individual himself, the individual with others in the group or the leader d) Normative structure, things that are included in the normative structure, among others, the purpose of norms and organizational ideology. The states that specific and operational organizational goals can reduce burnout. 


\section{Hypothesis}

The research hypothesis is formulated as follows:

1. Organizational design has a significant effect on burnout

2. Organizational design has a significant effect on performance

3. Organizational design and burnout have a significant effect on performance

\section{Material and Methods}

\section{Research strategy}

This thesis employed a quantitative analysis methodology with a cross-sectional approach. This thesis was done at Me-mother dan's and child hospital (rsia).

\section{Measurement}

Organizational design, which is used as a measurement in this study is the nurses' perception of the organizational design that is built by rsia. The evaluation criteria for organizational design are represented by variables, among others:

a. Formalization

b. Specialization

c. Hierarchy of authority

d. Complexity

e. Centralization

f. Professionalism

Burnout is a condition of physical, behavioral, and emotional fatigue induced by repeated exposure to conditions that demand a high degree of emotional commitment and a high expectation of personal performance. In this analysis, the burnout vector encompasses three dimensions: physical fatigue, depersonalization, and perceived inadequacy of professional achievement.

The amount of progress obtained by a nurse in their practice is referred to as excellence in research. That illustrates the quality and quantity of work done by a nurse. The below are the success indicators: 1) Supremacy. Job efficiency refers to how well a person executes the duties assigned to him or her. 2) Number. Job quantity applies to the number of hours individual works in a single day. This quantity of work may be determined by the pace at which each employee performs his or her duties. 3) Transparency. Responsibility for work entails an employee's knowledge of his or her duty to perform the work delegated by the company. 4) Cooperative effort. Employees may collaborate to complete tasks delegated by the company or department. 5) Take the initiative. Employees are capable of executing duties and taking action.

The descriptive analysis was defined by using Stemple Jr.'s modification to categorize the mean (mean) of a variable (Karambut, et al., 2004). Quite mild (1.0-1.8), low (1.9-2.6), moderate (2.7-3.4), strong (3.5-4.2), and very large (4.3-5.0) are all potential meanings. The Maslach Burnout Inventory (MBI) Scale is used to measure the degree of burnout faced by nurses.

\section{Population and sample}

The populations in this study were nurses in seven mother and child hospitals in the city of Medan.

\section{Sampling method}

The survey consisted of 143 nurses drawn from seven families. Purposive sampling was used to gather data, based on several criteria, namely: nurses who directly provide nursing services to patients, minimum education Diploma III or equivalent, willing to fill in the informed consent.

\section{Research object}

The object of this research is the organizational design, burnout, and performance of mother and child hospital nurses. 


\section{Data collection}

The data needed to analyze the problems in this study are primary data and secondary data. Data collection techniques through questionnaires and documentation study.

\section{Research instrument}

There were collected using a social support questionnaire and the Maslach Burnout Inventory (MBI) (Maslach et al. 1996), which is designed to assess three aspects of burnout syndrome. This tool scores on three sub-scales, namely emotion exhaustion, depersonalization disorder, and personal accomplishment. On a scale of 0-6, respondents show how often they feel different types of burnout. The higher the respondents' scores on depersonalization and emotional exhaustion, the higher their level of fatigue. The lower the score on personal achievement, the higher the burnout rate. This tool has been proven reliable, valid, and easy to run.

Table 3. Maslach Burnout Inventory Scale (MBI)

\begin{tabular}{llll}
\hline MBI Sub-scale & \multicolumn{3}{l}{ Experience Burnout Rate } \\
& Low & Moderate & High \\
\hline$\square$ Emosional Exaustion & $<15$ & $15-23$ & $>23$ \\
$\square$ Depersonalization & $<0$ & $4-8$ & $>8$ \\
$\square$ Personal Achievement & $>36$ & $30-36$ & $<30$ \\
\hline
\end{tabular}

\section{Data analysis}

The data analysis methodology used in this study is route analysis using the Partial Least Squares application SmartPLS (PLS). The direction model used in this analysis assumes that organizational architecture and burnout have a direct impact on efficiency. Additionally, the organizational architecture environment has an indirect impact on success through burnout.

\section{Results and Discussion Respondent profile}

Table 4. Respondent profile

\begin{tabular}{lllll}
\hline No $\quad$ Characteristics & Information & $\begin{array}{l}\text { Total } \\
\text { (Person) }\end{array}$ & $\begin{array}{l}\text { Percentage } \\
(\%)\end{array}$ \\
\hline $1 \quad$ Years of service & $1-5$ years & 60 & 41.96 \\
& & $6-10$ years & 26 & 18.18 \\
& $11-15$ years & 18 & 12.59 \\
& $16-20$ years & 21 & 14.68 \\
& & 18 & 12.59 \\
& Age & $21-25$ years & 18 & 12.59 \\
& & $21-25$ years & 26 & 18.18 \\
& 26-30 years & 30 & 20.98 \\
& 31-35 years & 31 & 21.68 \\
& 36-40 years & 20 & 13.98 \\
& 41-45 years & 14 & 9.79 \\
& 46-50 years & 4 & 2.79 \\
& L 51 years & 82 & 57.34 \\
& D-3Nursing & 56 & 39.16 \\
& Midwifery & & \\
& Academy & 5 & 3.49 \\
& S-1 Nursing & 0 & 0 \\
\hline
\end{tabular}

Source: Primary Data, 2020 
Respondent characteristics are characteristics of nurses who become respondents including age, gender, and years of service. The ages of nurses in this study varied from 21 years to 51 years. Nurses aged 36 to 40 years constitute the highest percentage, namely 31 people $(21.68 \%)$ of 143 people, and nurses aged 31 to 35 years are 30 people $(20.98 \%$ ), while the smallest percentage is found at the age over the age of 51 years, respectively four people $(2.79 \%)$. While the work tenure of nurses was the largest distributed at five years as many as $60(41.96 \%)$ people, while the working period of 21 to 25 years is 18 people $(12.59 \%)$. In addition, the nurses have the level of education d3Nursing are 82 people (57.34\%), and have no S2 Nursing.

\section{Overview of organizational design, nurse burnout, and performance}

The existence or general description of organizational design, burnout, and performance is presented in Table 4.

Table 5. Overview of organizational design, burnout and nurse performance

\begin{tabular}{llll}
\hline No & Variable & Mean & Category \\
\hline 1 & Organizational & 4.00 & Good \\
& design & & \\
2 & Burnout & 3.23 & Moderate \\
3 & Performance & 3.85 & High \\
\hline
\end{tabular}

Source: Primary data, 2020

Table 4 shows that in general, the respondent's perception of the organizational design of rsia is good, while the burnout level experienced by nurses is in the medium category, then the nurse's performance is high. The nurse's burnout was depicted as mild. Nurse burnout happens in the burnout dimension of mental exhaustion, in which nurses suffer emotional and exhaustion on a physical level as a result of their jobs being so hard. Generally, the output indicator implies a good/high degree of performance. The most important metrics of nurses' success are work ethics and engagement, which demonstrate nurses' commitment to their career and their role in teamwork. According to the Maslach Burnout Inventory (MBI), nurses experience a moderate level of emotional exhaustion and depersonalization, but a low/low level of personal achievement. Table 5 summarizes the burnout rates faced by hospital nurses using the Maslach Burnout Inventory (MBI) scale.

Table 6. The rate of burnout experienced is based on a scale Maslach Burnout Inventory (MBI)

\begin{tabular}{lll}
\hline MBI subscale & Mean & Category \\
\hline - Emotional Exhaustion & 15.02 & Moderate \\
- Depersonalization & & \\
- Personal Achievement & 4.28 & Moderate \\
& 41.37 & Low \\
\hline
\end{tabular}

Source: Primary Data, 2020 Organizational Design Analysis

The following conclusions were derived from tabulating respondents' responses on their views of the organization's organizational design:

1. Institutionalization. In terms of formalization, respondents viewed working hour rules to be in a moderate position, i.e. not too stringent but also not overly lax. Apart from that, the rules regulating dressing procedures in rsia are exceedingly stringent. The law governing the use of written records plays a significant role in the rsia's formalization process. Standardization of work is not particularly concerned with rsia, and some laws enforce incredibly stringent fines for each breach performed. By analyzing the current circum-stances, it is 
clear that health care providers in this situation have a reasonably high degree of formalization, according to respondents.

2. Concentration. In terms of specialization, respondents indicated that an explanation of task requirements has been included in rsia, although a small part. Similarly, the rsia's mission division has not yet achieved its full level. This suggests that there are already nurses who are assigned duties that are inappropriate for their job or branch. Additionally, respondents agree that there is no full power over the nurse when she is doing her duties. When they practice, they have to face pressure from other nurses or their supervisors. Thus, specialization is at a modest degree.

3. Authority Hierarchy. Respondents believe that the supervising / managing authority is necessary to delegate duties and that each superior / managing authority has a significant number of subordinates. Based on the study of this hierarchy of authority, it is possible to infer that the architecture is mechanistic.

4. Complimentary. In terms of difficulty, respondents believe that the rsia has a limited number of position levels and a limited number of positions. This suggests the health care organizations, which in this case is an rsia, are moderately nuanced.

5. Concentration. In terms of centralization, respondents believe that decision-making is not necessarily made by top management and that processes with fewer subordinates are preferable. This ensures that nurses are compensated for their participation in decision-making during rsia operations. According to the report, the organization is largely centralized.

6. Professionalism. In terms of integrity, respondents noted that in health care organizations, educational standards must be met in a hospital and that nurses often undergo instruction. This indicates that health care companies, in the respondent's opinion, exhibit a high degree of professionalism.

7. Technological creativity. According to respondents, health care providers make use of new technical resources. This is because the organization is involved in health care, which necessitates the use of advanced technologies to deliver superior treatment.

8. Environmental factors. In terms of environmental variables, health care providers have created a supportive atmosphere in which respondents have positive interactions with one another, a secure work environment, and organizations that are sensitive to nurses' welfare.

The results of the tabulation of the organizational design variable data based on the twenty-fours (24) The following properties are used as measuring features.

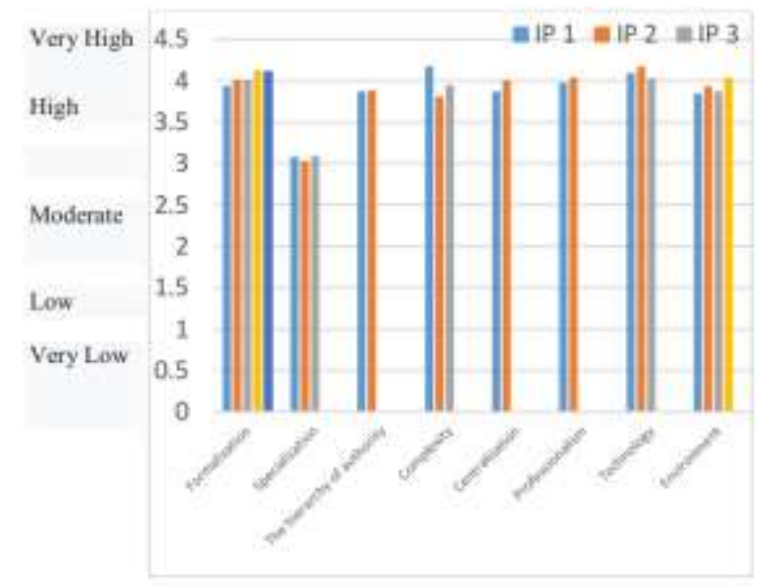

Figure 2. Organizational design data tabulation (Source: Primary Data, 2020) 
The organizational design of health care companies in this study has a mechanistic tendency. This is characterized, among others, by the existence of a high level of formalization, a fairly high level of centralization, training, or job experience that is comparatively modest. The regulation covers a vast region and is dominated by visual and written correspondence.

\section{Analysis of the influence of organizational design and organizational climate on burnout} Path Coefficients

Table 7. Path coefficients

\begin{tabular}{|c|c|c|c|c|c|}
\hline & \multirow{2}{*}{$\begin{array}{l}\text { Original } \\
\text { Sample } \\
\text { (O) }\end{array}$} & \multirow{2}{*}{$\begin{array}{l}\text { Sample } \\
\text { (M) }\end{array}$} & \multirow{2}{*}{$\begin{array}{r}\text { MeanStandard } \\
\text { (STDEV) }\end{array}$} & \multicolumn{2}{|c|}{ StatisticsP } \\
\hline & & & & $(\mathrm{O} / \mathrm{STDEV})$ & Values \\
\hline \multirow[t]{2}{*}{ Burnout -> performance } & & & & & \multirow{2}{*}{0.000} \\
\hline & 0.908 & 0.901 & 0.035 & 26.037 & \\
\hline \multirow{2}{*}{$\begin{array}{l}\text { Organizational design } \\
\text {-> burnout }\end{array}$} & & & & & \multirow[b]{2}{*}{0.000} \\
\hline & 0.949 & 0.950 & 0.015 & 63.660 & \\
\hline $\begin{array}{l}\text { Organizational design } \\
\text {-> performance }\end{array}$ & 0.586 & 0.590 & 0.237 & 3.738 & 0.000 \\
\hline
\end{tabular}

Source: Output Smart PLS 2020

Table 6 shows that the relationship between organizational design and burnout is significant with a T-statistic of 63.660 ( $>1.96)$. The original value of the sample is positive, namely 0.949 which indicates that the direction of the relationship between organizational design and burnout is positive. Thus, hypothesis $\mathrm{H} 1$ in this study which states that "organizational design affects burnout" is accepted. Table 6 shows that the relationship between burnout and performance is significant with the T- statistic of 26.037 (>1.96). The initial value of the sample is positive, namely 0.908 which means that the relationship between burnout and success is in a positive direction. Thus, hypothesis $\mathrm{H} 2$ in this study which states that "Burnout affects performance" is accepted. Table 6 shows that the relationship between organizational design and performance is significant with the T- statistic of 3.738 (>1.96). The initial value of the sample is positive, namely 0.586 which indicates that the direction The majority of the time, the relationship between organizational architecture and efficiency is favorable. Thus, hypothesis $\mathrm{H} 3$ in this study which states that "Organizational design affects performance" is accepted.

The findings of this study corroborate Utami's (2005) research, which identified a correlation between organizational design and burnout and its impact on performance. The research, burn-out has a significant effect on job satisfaction and motivation. When workers are happy with their careers, their drive to work improves as well, which results in improved efficiency (Maha-rani \& Akde, 2012).

\section{Conclusion}

1. The organizational design of health service companies in this study has a mechanistic tendency. This is characterized, among others, by a high level of formalization, a fairly high level of centralization, training, or job experience that is comparatively modest. Regulation over a vast region that is dominated by vertical and written contact.

2. Organizational design haves an effect on performance.

3. Organizational design and burnout affect performance

\section{Acknowledgment}

Without the excellent encouragement of our institution, this paper and the study that contributed to it would not have been feasible. On this occasion, we would like to express our profound gratitude to the Research at Universitas Sumatera Utara. 
On this occasion, the author also expresses his gratitude to the committee of the International Conference on Economics, Management and Accounting (1st ICEMAC 2020) for accepting this article for publication in the 1st ICEMAC Proceedings. I hope the 2nd ICEMAC can be imple-mented soon.

\section{References}

Baron, R. A. G. (1997). Behavior in organization: Understanding and managing the human side of wpork. Third Edition, Allyn and Bacon, Massachusset

Daft, R. L. (2016). Organization theory and design. Singapore: Cengage Learning.

Dale, T. (2011). Motivating employees, human resource management series. Jakarta: Elex Media Komputind

Dessler, G. (2015). Human resource management, 14th edition. Salemba Empat Publisher, Jakarta.

Fitriastuti, T. (2013). The influence of emotional intelligence, organizational commitment and organizational citizenship behavior on employee performance. Jurnal Dinamika Manajemen, 4(2), 1-5.

Gibson, J. L, Ivancevich, John, M., Donnelly, Jr, \& James, H. (2008). Organizations, behavior, structure, processes. International edition, Irwin. Mc Graw Hill. USA.

Hakim, L., \& Windijarto. (2016). Work productivity in terms of burnout and self-efficacy, Jurnal Psikologi Islam (JPI), Pusat Penelitan dan Layanan Psikologi, 13(2), 1-8.

Karambut, C.A., Eka, A.T., \& Noormijati. (2012). Analysis of the influence of emotional intelligence, job stress and job satisfaction on organizational commitment (A study on inpatient nurses at Panti Waluya Hospital Malang, Jurnal Aplikasi Manajemen, 10(2), 1-5.

Kurniawati, D., \& Solikhah (2012). The relationship between work fatigue and the performance of nurses in the inpatient ward of the Fatimah Islamic Hospital Kabupaten Cilacap. KES MAS, 6(2), 1-6.

Luthans, F. (2011). Organizational behavior 12th Ed. New York: McGraw-Hill.

Maharani, P. A., \& Akde, T. (2012). Job burnout with nurse performance in nursing care delivery. Jurnal Stikes, 5(2), 1-5.

Mangkunegara, A. P. (2015). Company human resource management. Bandung: Remaja Rosdakarya.

Maslach, C., Schaufeli, \& Leither. (2001). Job burnout. Annual Review of Psycology, 52, 114-117.

Mondy, R. W., \& Mondy, J. B. (2008). Human resource management. 10th edition. Jakarta: Erlangga Publisher.

Robbins, S. P., \& Judge, T. A. (2009). Organizational behavior (13th Edition). New Jersey: Prentice-Hall International Inc.

Suandi T., Ismail, I. A., \& Othman, Z. (2014). Relationship between organizational climate, job stress and job performance officer at state education department. International Journal of Education \& Literacy Study, 2(1), 17-28.

Utami, D. R. R. B. (2005). Relationship between organizational climate and job satisfaction of nurses in inpatient rooms RS PKU Muhammadiyah Karanganyar. Jurnal Kesehatan Surya Medika, 1(1), 1-7. 